\title{
Michał Nowicki
}

Uniwersytet Wrocławski

e-mail: michal.nowicki@uwr.edu.pl

ORCID: 0000-0002-2930-8469

\section{BANKRUCTWO PAŃSTWA - FAKT CZY MIT?}

\section{BANKRUPTCY OF A STATE - TRUTH OR MYTH?}

DOI: $10.15611 / \mathrm{pn} .2019 .3 .06$

JEL Classification: E66, F34

Streszczenie: Celem niniejszej pracy jest zbadanie, czy państwa naprawdę bankrutują. Autor korzysta z analizy i krytyki literatury naukowej, metody opisowej i statystycznej, by odpowiedzieć na postawione w tytule pytanie. Na potrzeby artykułu sformułowane zostają: hipoteza główna H1 - państwo może zbankrutować, a także hipotezy pomocnicze H1a - państwo może zbankrutować sensu stricto, H1b - państwo może zbankrutować sensu largo. W celu ich weryfikacji autor analizuje definicje bankructwa dostępne w piśmiennictwie naukowym, dokonuje przeglądu literatury traktującej o problemach finansowych państw, by następnie zidentyfikować kluczowe czynniki wpływające na to, że państwo uważane jest za bankruta (lub za zagrożone bankructwem). W końcowej części przytoczone zostają przykłady bankructw państw opisane w literaturze naukowej. Na tej podstawie sformułowane zostają wnioski oraz oceniona zostaje prawdziwość hipotez.

Słowa kluczowe: państwo, bankructwo, sovereign default, niewypłacalność.

Summary: The aim of this work is to investigate whether states are really going bankrupt. The author uses the analysis and criticism of scientific literature, descriptive and statistical methods to answer the question put in the title. For the purposes of the article, the main hypothesis H1 - State may go bankrupt; and the two auxiliary hypotheses: H1a - State may go bankrupt in the strict sense; H1b - State may go bankrupt in the broad sense; were formulated. In order to verify them, the author examines the definitions of bankruptcies, reviews the literary covering issue of the financial problems of states, and identifies the key factors that affect the state considered to be bankrupt (or being threatened by bankruptcy). In the final section, examples of the bankruptcy of the countries described in the scientific literature are cited. On this basis, the final conclusions are formulated and the veracity of the hypotheses is done.

Keywords: state, bankruptcy, sovereign default, insolvency.

\section{Wstęp}

O bankructwie poszczególnych państw można usłyszeć bardzo często, śledząc wiadomości czy przysłuchując się publicznej dyskusji. W XXI wieku bodaj najsłynniejszym potencjalnym państwem bankrutem jest Grecja, ale przykładów jest znacznie 
więcej. Właściwie w mediach co chwilę słyszymy, że państwo X jest na skraju bankructwa lub jest bankructwem zagrożone. Ale czy państwa tak naprawdę bankrutują? Co oznacza bankructwo w kontekście państwa? Celem niniejszego artykułu jest weryfikacja hipotezy: państwo może zbankrutować (H1). Aby tego dokonać, najpierw podjęto próbę zdefiniowania bankructwa na gruncie ekonomii i prawa w ujęciu ogólnym, tyczącym się zwyczajowo przedsiębiorstw. Na tej podstawie zostaną sformułowane kryteria oznaczające bankructwo państwa, jak również postawione zostaną dwie hipotezy pomocnicze: państwo może zbankrutować sensu stricto (H1a) oraz państwo może zbankrutować sensu largo (H1b) Kolejnym krokiem był przegląd literatury polsko- i anglojęzycznej dotyczącej bankructwa państwa. Następnie podjęto próbę wskazania przypadków bankructw państw w XX i XXI wieku na podstawie przykładów wymienionych w literaturze naukowej. Na podstawie wyżej wymienionych elementów dokonana zostaje ocena postawionej hipotezy i sformułowane zostają wnioski końcowe.

\section{Bankructwo - ujęcie definicyjne}

Analiza polskojęzycznych źródeł dotyczących bankructwa pokazuje nam niejednoznaczność tego pojęcia. Autorzy są zgodni co do tego, że jest to termin używany na gruncie ekonomii, mający swój najbliższy odpowiednik w języku prawniczym w pojęciu ,upadłości”. Należy jednak zaznaczyć, iż nie są to pojęcia tożsame. Upadłość jest terminem dookreślonym, opisanym m.in. w ustawie Prawo upadłościowe. Ogłasza ją sąd w stosunku do określonych w ustawie podmiotów, spełniających ustawowe kryteria. Bankructwo zaś jest pojęciem szerszym. Prusak pisze: „Nie każde bankructwo ekonomiczne musi oznaczać więc upadłość w rozumieniu prawa, lecz każda upadłość w sensie prawnym oznacza bankructwo ekonomiczne" [Prusak 2004, s. 184-185]. Jura definiuje bankructwo jako trwały stan, w wyniku którego formalnie zostaje zakończona działalność danego podmiotu lub jako zakończenie działalności nieefektywnego podmiotu w wyniku trwałej utraty płynności i wysokiego zadłużenia [Jura 2016, 293]. Boratyńska zaś pisze, że w sensie ekonomicznym bankructwo oznacza, że przedsiębiorstwo nie jest w stanie na czas regulować swoich należności, a wartość jego majątku jest niewystarczająca na ich pokrycie [Boratyńska 2009, s. 175]. Pociecha proponuje definicje rozróżniającą wąskie i szerokie rozumienie bankructwa. W tym pierwszym za bankrutów uznajemy te firmy, wobec których sąd ogłosił upadłość, w tym drugim znaczeniu zaś są to zarówno firmy po decyzji o upadłości, jak i „te firmy, które rynek uznaje za stanowiące zagrożenie dla uczestników obrotu gospodarczego" [Pociecha 2007, s. 64-65]. Świerk i Banach definiują bankructwo tak: „Bankructwo jest pojmowane jako kategoria oznaczająca sytuację, w której przedsiębiorca nie posiada żadnego majątku. Doprowadza to do stanu, w którym nie można przeprowadzić nawet postępowania upadłościowego, ponieważ nie ma na to środków pieniężnych. Wyraża to więc całkowitą stratę wierzycieli przedsiębiorstwa i zamknięcie działalności [...] Nazwanie przedsiębiorcy 
bankrutem może również oznaczać, że bez pomocy zewnętrznej nie jest on w stanie prowadzić działalności” [Świerk, Banach 2013, s. 442].

Widzimy więc, że w świetle definicji przedstawianych w polskim piśmiennictwie naukowym można stwierdzić, że bankructwo to stan niewypłacalności podmiotu gospodarczego, który nie tylko nie jest w stanie regulować swoich należności, ale także nie posiada majątku wystarczającego na pokrycie roszczeń wierzycieli. W konsekwencji dany podmiot gospodarczy przestaje istnieć. Jako bankructwo postrzega się również sytuację, w której przedsiębiorstwo traci możliwość regulowania swoich zobowiązań i dalszego funkcjonowania bez pomocy z zewnątrz. Oznacza to, że podmiot nie upada całkowicie, nie zaprzestaje działalności, ale może ją kontynuować po otrzymaniu zewnętrznego wsparcia. Jest to niezwykle istotna różnica w świetle przeprowadzanych rozważań. Dlatego na potrzeby niniejszego artykułu autor zastosuje podział na rozumienie bankructwa sensu stricto i sensu largo. Bankructwo sensu stricto to stan, w którym podmiot traci możliwość dalszego funkcjonowania w wyniku nadmiernego zadłużenia i nieefektywności gospodarowania, w związku z czym przestaje istnieć jako odrębny byt. Bankructwo sensu largo zaś to sytuacja, w której podmiot traci możliwość regulowania swoich zobowiązań, a jego dalsze istnienie uzależnione jest od udzielonej mu pomocy zewnętrznej.

\section{Przegląd literatury dotyczącej bankructwa/niewypłacalności państwa}

Jak piszą autorzy raportu „Revisiting Sovereign Bankruptcy”, temat bankructwa państw od lat 80. XX wieku co jakiś czas wraca na agendę w debacie międzynarodowej. Podają oni przykład kryzysu zadłużeniowego Ameryki Łacińskiej właśnie w latach 80., w latach 90. kryzys w Meksyku i Rosji, a w XXI wieku - kryzysu zadłużeniowego strefy euro, z osławioną Grecją na czele [Buckheit i in. 2013, s. 1-4]. Obszernie o bankructwie państw, w kontekście zagrożenia tymże państw europejskich, pisze Klimowicz. Jednocześnie autorka ta sama przyznaje, że jest to termin mglisty, niezdefiniowany i tak naprawdę nie wiemy, co on do końca oznacza. Nie przeszkadza jednak jej to w opisywaniu długiej historii bankructw państw. Zestawia ona także termin bankructwa i niewypłacalności, precyzując ten drugi termin i podając, za MFW, kryteria oceny zagrożenia tym drugim [Klimowicz 2014, s. 336-339] . Ciekawe ujęcie teoretyczne, „ekonomiki niewypłacalności państwa” prezentują autorzy artykułu The economics of sovereign defaults. Pokazują oni ujęcie teoretyczne samego zagadnienia, zestawiają sektor prywatny i państwo pod omawianym kątem, wskazują determinanty powstawania tego zjawiska, jak również jego konsekwencje [Hatchondo, Martinez, Sapriza 2007, s. 163-187]. Z kolei Buckley zaczyna swój artykuł od bardzo ciekawego cytatu. Przytacza on słowa byłego prezesa Citicorp Waltera Wristona, który stwierdził, że państwa nigdy nie bankrutują. Argument Wristona na poparcie tego stwierdzenia brzmiał: „W najsłabiej rozwiniętych państwach 
nie następuje bankructwo, bo nie znika ich infrastruktura, nie znika kapitał ludzki, nie znikają zasoby naturalne, więc ich wierzytelności nie przekraczają ich aktywów, co jest kluczem w bankructwie". Sam Buckley jednak kategorycznie się z tą argumentacją, a przez to z samym stwierdzeniem, nie zgadza. Zwraca on uwagę, że infrastruktura może ulec degradacji, kapitał ludzi spaść w wyniku chorób lub krachu systemu edukacji, a zasoby naturalne, o ile w ogóle są w znacznych ilościach, mogą ulec wyczerpaniu przez ekstensywne wydobycie. Same zaś aktywa państwa, w odróżnieniu od aktywów przedsiębiorstwa, nie są „,sprzedawalne” („saleable”). W dalszej części autor ten doprecyzowuje, że oczywiste jest, iż bankructwo państwa ma inny charakter niż bankructwo przedsiębiorstwa. Państwa bankruci nie znikają z mapy, ich majątek nie jest rozdzielany na dłużników [Buckley 2009, s. 1189-1196]. Przeglądu różnych ujęć teoretycznych dotyczących bankructwa państwa dokonuje Boratyńska w artykule Ekonomiczne oraz społeczne aspekty bankructwa państwa. Przytacza ona m.in. opinię prof. Orłowskiego, który twierdzi, że państwa mogą zbankrutować, stara się także przedstawić najczęstszy mechanizm bankructwa państw, powołując się na Ferguson, a także Reinhart i Rogoffa. Interesującym elementem artykułu jest powołanie się na indeks upadłości autorstwa D\&B [Boratyńska 2013].

Bardzo obszerny pod względem przytoczonych badań na temat bankructwa państw jest artykuł Szeli, Mentla i Brożyny, których celem jest zbudowanie modelu do estymacji ryzyka bankructwa państwa. Autorzy ci stoją, implicite, na stanowisku, że państwo może bankrutować, a co więcej, państwa bankrutują często (m.in. Islandia w trakcie ostatniego kryzysu ekonomicznego). Zwracają oni uwagę także na to, że jakkolwiek literatura (anglojęzyczna) dotycząca zjawiska sovereign default jest rozległa, to nie jest homogeniczna. Przejawia się to w różnych podejściach do głównej przyczyny bankructwa państwa (kryzys finansowy, bankowy, zadłużeniowy) [Szela, Mentel, Brożyna 2016, s. 839-842]. Bardzo interesujące pragmatyczne podejście do tego zagadnienia prezentuje Sandleris. Autor ten w artykule The Costs of sovereign default: theory and empirical evidence rozważa koszty, z jakimi może spotkać się państwo ogłaszające bankructwo. Tym samym nie tylko zakłada, że państwa mogą bankrutować, ale pokazuje, co muszą uwzględnić, by im się to opłacało [Sandleris 2016, s. 1-25]. Wpisuje się to w szerszy trend, wyraźnie zauważalny wśród ekonomistów w ostatnich latach, aby nie demonizować długu publicznego i nie walczyć z nim za wszelką cenę.

Z analizy polsko- i anglojęzycznych źródeł wyłania się także obraz zagadnienia, które budzi dużo kontrowersji. Wielu autorów, rozpatrując zagadnienie od strony zarówno prawnej, jak i ekonomicznej, zwraca uwagę na pewien deficyt formalny. Mimo iż opisywane zagadnienie nie jest nowe, wciąż brakuje ram prawnych i jasno zdefiniowanych kryteriów określających, czy możemy mówić o bankructwie państwa, czy tylko o jego niewypłacalności. Jeżeli zaś dopuszczamy możliwość bankructwa państwa, to pod jakimi warunkami do niego dochodzi? W tym zakresie rzeczywistość międzynarodowa zdaje się wciąż wyprzedzać stan prawny. 


\subsection{Bankruptcy, insolvency, sovereign default - problemy semantyczne}

Dokonując przeglądu literatury anglojęzycznej na temat niezdolności państwa do regulowania swoich zobowiązań, można spotkać się z dość dużą różnorodnością pojęć, które używane są do opisania tego zjawiska. O ile autorzy używający terminu bankruptcy oraz insolvency niewątpliwie mają na myśli, kolejno, bankructwo i niewypłacalność, o tyle pojęcie sovereign default jest niezwykle problematyczne. Pojęciem tym posługuje się m.in. Międzynarodowy Fundusz Walutowy, co z pewnością świadczy o wysokim stopniu formalności. W toku przeprowadzanych konsultacji językowych okazało się, że nie istnieje jednoznaczny kompromis co do tego, które z dwóch znaczeń można przypisać rzeczonemu terminowi. Paradoksalnie ten brak konkluzywnego rozwiązania problemu jest istotną informacją. Być może, co oddaje język angielski, nie da się przypisać jednoznacznie w stosunku do państwa terminów, które stworzone zostały do opisu sytuacji przedsiębiorstw lub gospodarstw domowych. Innymi słowy państwa przeżywające poważne problemy finansowe znajdują się gdzieś pomiędzy niewypłacalnością i bankructwem i to jest sedno terminu sovereign default. Inny wniosek, równoprawny względem poprzedniego, jest taki, że bankructwo państwa pod względem znaczenia jest czymś innym niż bankructwo po prostu. Dodanie ,państwa” do słowa „bankructwo” implikuje inne rozumienie całego terminu.

Sam fakt, że w anglojęzycznej literaturze naukowej to samo zjawisko występuje pod różnymi nazwami, wskazuje na to, że nie ma zgody wśród autorów co do tego, czy państwa bankrutują, czy dzieje się z nimi coś innego.

\section{Determinanty bankructwa/niewypłacalności państwa}

Rozbudowane badania na temat wpływu długu publicznego na wzrost gospodarczy i inflację przeprowadzili m.in. Reinhar i Rogoff oraz Fucceri i Zdziecka. Pierwsza para autorów w swoim badaniu wykazała, że w grupie państw wysoko rozwiniętych granicznym progiem zadłużenia w relacji do PKB jest $90 \%$. Po jego przekroczeniu widoczny jest spadek wzrostu gospodarczego w badanych państwach. Podobne wyniki uzyskano w grupie państw rozwijających się. Badania te nie wykazały korelacji między poziomem długu a inflacją [Reinhart, Rogoff 2010]. Z kolei w badaniu Furceriego i Zdzienickiej widzimy, że pierwszym progiem, po którym w badanych państwach występował spadek dynamiki wzrostu gospodarczego, było $70 \%$, kolejnym 90\% [Furceri, Zdzienicka 2012, s. 736]. Oba badania wskazują jednoznacznie na negatywny wpływ wysokiego zadłużenia na gospodarkę. Powiązane jest to z koniecznością cięcia wydatków lub podwyższaniem podatków. Szczególnie zjawisko to występuje w krajach, które mają wysokie zadłużenie zagraniczne i działają niejako pod presją rynków międzynarodowych, które w reakcji na ich wzrost długu podnoszą stopy procentowe [Reinhart, Rogoff 2010]. Zestawienie zmian w kosztach obsługi długu w stosunku do wzrostu zadłużenia przedstawia Mentzen. $\mathrm{Z}$ jego ana- 
lizy wynika, że wzrost deficytu silniej oddziałuje na wzrost oprocentowania obligacji niż wzrost zadłużenia. W obu przypadkach, mimo istotnych różnic między przytoczonymi badaniami, można stwierdzić, że związek między tymi czynnikami jest istotny i silnie oddziałuje na sytuację gospodarczą kraju [Mentzen 2012, s. 80].

Bardziej kompleksowe ujęcie omawianego zagadnienia przedstawia Międzynarodowy Fundusz Walutowy. Organizacja ta wydała dokument, w którym określa 10 czynników wpływających na wzrost ryzyka utraty płynności finansowej przez państwo. Są to:

- całkowite zadłużenie zagraniczne jako \% PKB,

- krótkoterminowe zadłużenie w relacji do rezerw walutowych,

- dług publiczny w relacji do wpływów budżetowych,

- realna dynamika PKB,

- inflacja,

- rentowność papierów skarbowych,

- kurs walutowy (przewartościowanie waluty),

- kurs walutowy (zmienność),

- potrzeby zewnętrznego finansowania w relacji do rezerw walutowych,

- liczba lat do najbliższych wyborów prezydenckich.

Drzewo decyzyjne (rys. 1), na którym bazuje powyższa lista, jest bardzo interesującą metodą badania ryzyka wystąpienia problemów finansowych w państwach. Widać, że zdaniem autorów najważniejszym czynnikiem, umieszczonym na szczycie, jest wielkość zadłużenia zagranicznego. Za próg różnicujący przyjęto wartość $50 \%$ PKB. Jeśli wartość ta przekracza próg, to według Manasse i Roubiniego ryzyko kryzysu wzrasta z 20,5\% do 45,4\%. Jeśli wysokiemu zadłużeniu zagranicznemu towarzyszy dwucyfrowa inflacja (powyżej $10,47 \%$ r/r), to ryzyko kryzysu wynosi już $66,8 \%$. Drugim progiem w tym wskaźniku jest $19,1 \%$, pod warunkiem że: (1) krótkoterminowe zadłużenie zagraniczne przekracza 134\% rezerw walutowych i (2) okres do kolejnych wyborów nie przekracza pięć i pół roku. Jeśli te dwa warunki zostaną spełnione oraz (3) zadłużenie zagraniczne współistnieje z relatywnie sztywnym kursem walutowym, to ryzyko kryzysu wynosi $41,5 \%$. W tej ścieżce na drzewie empirycznym najciekawszym wskaźnikiem jest czas do następnych wyborów prezydenckich. $\mathrm{Z}$ opisu metodologii badań można uzyskać informację, że zmienna ta została wytypowana jako jedna z 10 najistotniejszych z grupy 50 zmiennych mogących mieć wpływ na badane zjawisko. Okazało się, że ma on silniejsze oddziaływanie niż czas do kolejnych wyborów parlamentarnych. Jest to zarazem jedyny nieekonomiczny czynnik w zestawieniu. Zwrócić należy uwagę także na złożoność analizy ryzyka kryzysu, a w efekcie potencjalnej niewypłacalności/bankructwa. Opisywana metoda bardzo wyraźnie przeczy powszechnym w dyskusji publicystycznej na temat omawianego zagadnienia prostym (i fałszywym) schematom przyczynowo-skutkowym. Żaden z czynników w pojedynkę nie może być rozpatrywany jako jednoznaczny wskaźnik tego, że dane państwo jest poważnie narażone na utratę płynności finansowej. Co więcej, na omawianym schemacie istnieją tylko trzy 


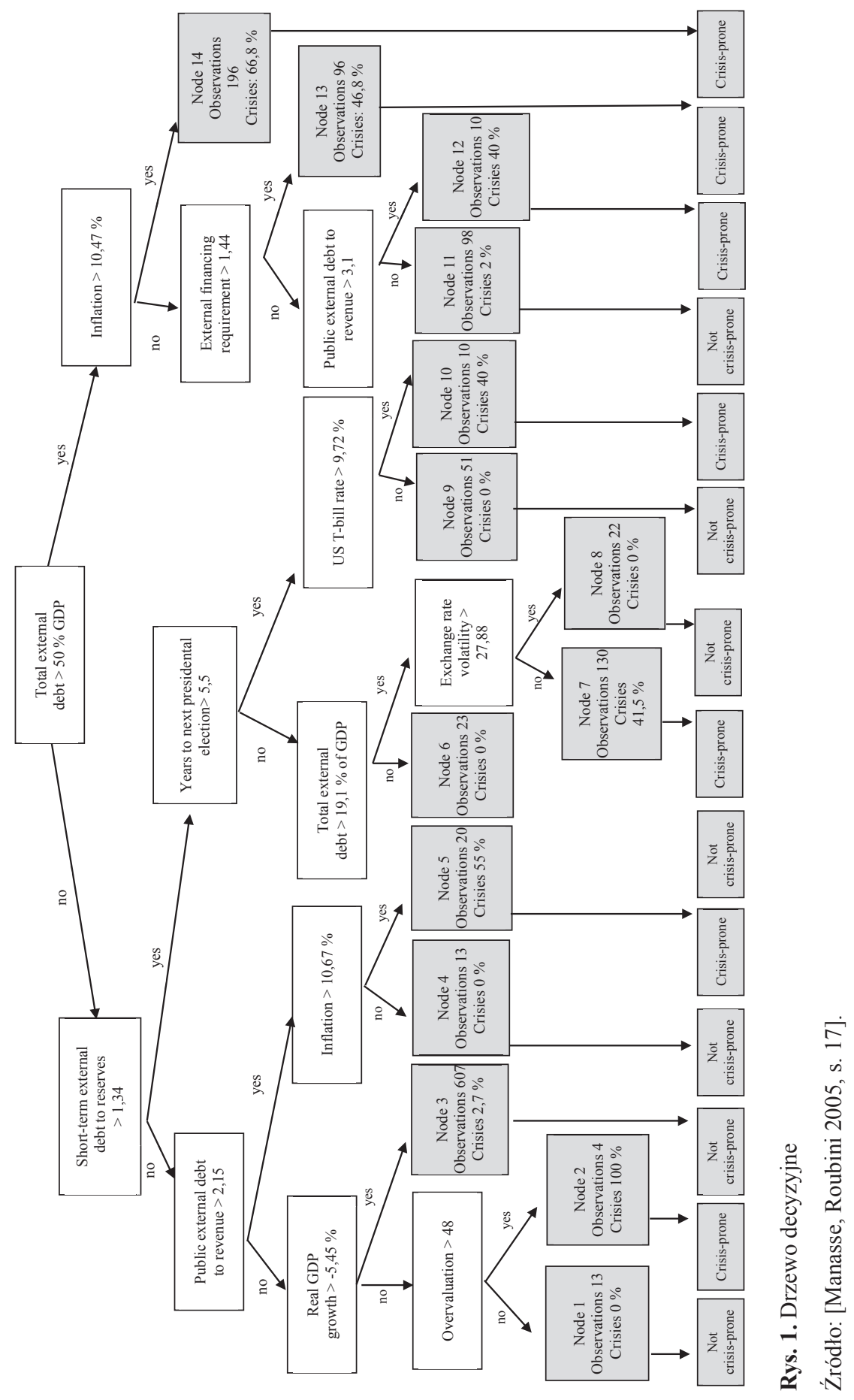


ścieżki, które przewidują kombinację skutkującą prawdopodobieństwem wyższym niż 50\%. Są to:

- (1) zadłużenie zagraniczne powyżej $50 \%$, (2) inflacja powyżej 10,47\%, które w efekcie prowadzą do prawie $67 \%$ szansy wystąpienia kryzysu;

- (1) zadłużenie zagraniczne poniżej 50\%, (2) krótkookresowy dług zagraniczny mniejszy niż 134\% rezerw walutowych, (3) zewnętrzny dług publiczny przekraczający $215 \%$ przychodów i (4) inflacja przekraczająca $10,47 \%$. Skutkuje to prawdopodobieństwem kryzysu rzędu 55\%;

- (1) zadłużenie zagraniczne poniżej 50\%, (2) krótkookresowy dług zagraniczny mniejszy niż $134 \%$ rezerw walutowych, (3) zewnętrzny dług publiczny nieprzekraczający $215 \%$ przychodów, (4) realny wzrost PKB mniejszy niż -5,45\% i (5) przewartościowanie kursu krajowej waluty o ponad 48\%. Skutkuje to, zdaniem autorów, stuprocentową pewnością kryzysu.

Niewątpliwą zaletą omawianej metody analitycznej jest fakt, że autorzy oparli ją na konkretnych przypadkach państw, w których wystąpił kryzys. Widzimy zatem, która ze ścieżek finalnie skutkowała poważnymi problemami gospodarczymi, w jakim kraju i w jakim roku. Warto zatem przyjrzeć się bliżej konkretnym przypadkom opisywanym w literaturze jako państwa, które zbankrutowały lub ogłosiły niewypłacalność.

\section{Przypadki bankructwa lub niewypłacalności państwa}

Jak wspomniano powyżej, Manasse i Roubini podają długą listę państw, które w wyniku kombinacji opisywanych przez nich czynników popadły w problemy z wypłacalnością, płynnością lub podjęły decyzję o ogłoszeniu „bankructwa” po kalkulacji korzyści i kosztów z takiego rozwiązania. Słowo „bankructwo” zostało wzięte w cudzysłów, gdyż autorzy ci używają terminu default tylko w stosunku do państw, które świadomie nie chcą spłacać swojego zadłużenia. Wśród państw rozwijających się, które doświadczyły problemów z finansowaniem długu od 1970 do 2002 roku, znalazły się m.in. Argentyna, Brazylia, Peru, Wenezuela, które w tym okresie trzykrotnie przestawały regulować swoje należności. Najdłużej w stanie niewypłacalności/bankructwa pozostawało Peru (19 lat), a najkrócej Wenezuela (10 lat). Rekordzistą w zestawieniu jest Republika Dominikany, która zdaniem autorów w sytuacji upadłości finansowej przebywała od 1981 roku do końca badanego okresu. Ogólnie w opisywanych ramach czasowych Manasse i Roubini przedstawiają 31 państw, które doświadczyły problemów finansowych skutkujących zaprzestaniem spłacania długów [Manasse, Roubini 2005, s. 9]. Znacznie rozleglejszą bazę przedstawia Bank of Canada. W 2017 roku w przygotowanym przez tę instytucję raporcie znalazło się 145 krajów, które od 1960 roku odmówiły spłaty zadłużenia zagranicznego lub krajowego. Były wśród nich zarówno państwa zaklasyfikowane jako HIPC (Highly Indebt Poor Countries), takie jak Afganistan czy Benin; kraje rozwijające się: Kambodża, Fidżi, Iran; rynki wschodzące: Węgry, Indonezja, jak i państwa 
wysoko rozwinięte: Grecja, Irlandia, Cypr [Bank of Canada 2017]. Zastosowana $\mathrm{w}$ tym raporcie metodologia jest bardzo restrykcyjna, przez co liczba krajów jest bardzo wysoka.

Krukowska w swoim artykule dla magazynu „Forbes” pisze o 80 przypadkach bankructw w ostatnich 200 latach. Wśród krajów, które bankrutowały, wymienia ona Argentynę w 2002 roku, Cypr w 2013 roku, Islandię w 2008 roku, Portugalię w 2011 roku, Rosję w 1998 roku, Dubaj w 2009 roku, Indonezję w 1997 roku, a także Wenezuelę i Grecję, czyli dwa najbardziej znane obecnie państwa omawiane w kontekście bankructwa [Krukowska 2016]. We wszystkich przypadkach mowa jest o bankructwie sensu largo, w którym kraj formalnie nie upada, gdyż otrzymuje pomoc zewnętrzną, dzięki której może dalej funkcjonować. Istotnym elementem każdego z zestawień jest rating wystawiony danemu państwu. Mimo niewątpliwie nadwątlonej reputacji agencji ratingowych, dalej zarówno w mediach, jak i w pracach naukowych kryterium uznania państwa za bankruta często opiera się właśnie na ich ocenie. Może to budzić zastrzeżenia, gdyż w przeszłości wielokrotnie oceny te okazywały się błędne, a kryteria ich wystawiania budziły kontrowersje. Co więcej, rating ma charakter subiektywnej oceny, wydanej przez podmiot oceniający, czyli przyznanie tzw. śmieciowego ratingu, wskazującego na bankructwo, może, ale nie musi oznaczać, że dane państwo faktycznie długookresowo nie jest w stanie regulować swoich zobowiązań.

\section{Wnioski}

Analizując literaturę polsko- i anglojęzyczną, można zauważyć, jak wiele kontrowersji wzbudza temat bankructwa państwa. Samo bankructwo to termin niemający umocowania w prawie, w ujęciu ekonomicznym zaś niejednoznaczny. Ta niejednoznaczność powoduje, że odpowiedź na pytanie „Czy państwo może zbankrutować?” zależy od przyjętej definicji bankructwa. Na potrzeby niniejszego artykułu, obok hipotezy głównej mówiącej, że państwo może zbankrutować, zostały sformułowane dwie hipotezy pomocnicze. Hipoteza 1a - „Państwo może zbankrutować sensu stricto" z pewnością jest fałszywa. Jeśli za bankructwo sensu stricto uznamy stan, w którym podmiot bankrutujący przestaje istnieć w wyniku tego, że jego zobowiązania są większe niż posiadane aktywa, to jednoznacznie można stwierdzić, że nie ma to zastosowania do państw. Przez cały wiek XX i pierwsze lata XXI wieku nie zaistniał ani jeden przypadek, by państwo zniknęło z mapy z powodu swojego zadłużenia. Hipoteza $1 b$ - „Państwo może zbankrutować sensu largo” jest prawdziwa. W tym rozumieniu bankructwo oznacza konieczność otrzymania pomocy zewnętrznej do dalszego istnienia. Liczne przypadki opisane jako „bankructwo państwa” zawsze oznaczały sytuację, w której państwo zwraca się o pomoc finansową umożliwiającą mu regulację najważniejszych zobowiązań i dalsze funkcjonowanie lub ją otrzymuje. Pomoc ta była udzielana ex post lub ex ante i miała różne źródła, ale każdorazowo miała charakter zewnętrzny, co spełnia warunki szerokiej definicji 
bankructwa. Jak zatem ocenić główną hipotezę? Być może niesatysfakcjonującą, ale jedyną możliwą odpowiedzią na to pytanie jest to, że państwa bankrutują na swój sposób. Termin „bankructwo” w kolokacji z „państwem” zmienia swoje znaczenie. W języku angielskim zostało to uchwycone w terminie sovereign default, które obejmuje swoim znaczeniem zarówno to, gdy państwo trwale traci zdolność do regulowania swoich zobowiązań, sytuację, gdy państwo ma czasowe problemy z płynnością, jak i sytuację, w której władze podejmują świadomą decyzję o nieregulowaniu zobowiązań, bo jest to dla nich korzystniejsze niż spłacanie długów. Jest to zatem zakres znaczeniowy wykraczający znacznie poza rozumienie słowa „bankructwo” w języku polskim.

W obszarze ekonomii głównego nurtu panuje powszechne przekonanie o szkodliwości nadmiernego zadłużania się oraz prowadzenia ekspansywnej polityki monetarnej i fiskalnej w długim okresie. Jednocześnie ekonomia głównego nurtu nie daje odpowiedzi na to, jaka jest ostateczna sankcja za nieprzestrzeganie tych reguł. Historia pokazuje nam, że od czasu ukształtowania się gospodarki kapitalistycznej w XIX wieku swoje bankructwo ogłaszały bardzo liczne państwa. Wiele z nich dzisiaj doskonale prosperuje. Być może rację ma heterodoksyjna Nowoczesna Teoria Pieniądza (MMT) i w niej powinniśmy szukać odpowiedzi?

\section{Literatura}

Bank of Canada, 2017, Database of Sovereign Defaults, Technical Report No. 101 / Rapport technique no. 101.

Buckheit L.C. i in., 2013, Revisiting sovereign bankruptcy, Brookings Institution.

Buckley R., 2009, The bankruptcy of nations: an idea whose time has come, The International Lawyer, 49(3).

Boratyńska K., 2009, Koszty bankructwa przedsiębiorstwa na świecie i w Polsce-przeglad dotychczasowych badań, Zeszyty Naukowe SGGW w Warszawie. Ekonomika i Organizacja Gospodarki Żywnościowej, nr 78.

Boratyńska K., 2013, Ekonomiczne oraz społeczne aspekty bankructw państw. Ekonomia dla przyszłości: odkrywać naturę i przyczyny zjawisk gospodarczych: IX Kongres Ekonomistów Polskich, PTE, Warszawa [dokument elektroniczny].

http://www.pte.pl/kongres/referaty/Boraty $\%$ C $5 \% 84$ ska $\% 20$ Katarzyna/Boraty $\%$ C5\%84ska $\% 20$ Katarzyna $\% 20-\% 20$ EKONOMICZNE\%20ORAZ\%20SPO $\%$ C5\%81ECZNE\%20ASPEKTY\%20 BANKRUCTWA \%20PA\%C5\%83STW.pdf.

Furceri D., Zdzienicka A., 2012, How costly are debt crises?, Journal of International Money and Finance, vol. 31.

Hatchondo J.C., Martinez L., Sapriza H., 2007, The Economics of Sovereign Defaults, Economic Quarterly, vol. 93(2).

Jura B., 2016, Upadłość przedsiębiorstw na rynku publicznym i niepublicznym w Polsce, Finanse. Czasopismo Komitetu Nauk o Finansach PAN, 1(9).

Klimowicz M, 2014, Bankructwo państw europejskich, [w:] Florczak A., Lisowska A. (red.), Organizacje międzynarodowe $w$ działaniu, OTO-Wrocław, Wrocław. 
Klimowicz M., 2014, Niewypłacalność państw strefy euro, [w:] Pacześniak A., Klimowicz M. (red.), Procesy integracyjne i dezintegracyjne w Europie. Podręcznik akademicki, OTO-Wrocław, Wrocław.

Krukowska M., 10 spektakularnych bankructw krajów, https://www.forbes.pl/wiadomosci/bankructwogrecji-10-panstw-ktore-tez-zbankrutowaly/yw35xtx (dostęp 17.03.2019).

Manasse P., Roubini N., 2005, Rules of Thumb” for Sovereign Debt Crises, IMF Working Paper, $\mathrm{WP} / 05 / 42$.

Mentzen S., 2012, Koszty dlugu publicznego i bankructwo państwa, Acta Universitatis Nicolai Copernici, EKONOMIA XLIII, nr 1, Torun.

Pociecha J., 2007, Problemy prognozowania bankructwa firmy metoda analizy dyskryminacyjnej, Acta Universitatis Lodziensis. Folia Oeconomica, nr 205.

Prusak B., 2004, Jak rozpoznać potencjalnego bankruta?, Prace Naukowe Katedry Ekonomii i Zarządzania Przedsiębiorstwem, red. F. Bławat, tom 3, Wydawnictwo Politechniki Gdańskiej, Gdańsk.

Reinhart C., Rogoff K., 2010, Growth in a time of debt, American Economic Review Papers and Proceedings.

Sandleris G., 2016, The costs of sovereign default: theory and empirical evidence, Economia, 16(2).

Szela B., Mentel G., Brożyna J., 2016, In search of insolvency among European countries, Economic Research-Ekonomska Istraživanja, 29:1.

Świerk J., Banach A., 2013, Upadłość polskich przedsiębiorstw w latach 2009-2012, Zarządzanie i Finanse, 2/2. 